\title{
Research on Regulation Mechanism of Aquaporin 3 and Its Effects on Skin
}

Xiaoyue Wang, Yan Xue, Zeyuan Dong, Yinmao Dong, Li Li

China Cosmetic Collaborative Innovation Center, Beijing Technology and Business University, Beijing, China

*Corresponding author: Li Li, China Cosmetic Collaborative Innovation Center, Beijing Technology and Business University, No. 11/33, Fucheng Road, Haidian District, Beijing, China Tel.: +861068987110

Email: lili2212@163.com

Received March 30, 2017

Revised April 22, 2017

Accepted April 28, 2017

Published June 30, 2017

\begin{abstract}
Aquaporin 3 (AQP3) plays an important role in the expression of various skin-related diseases such as vitiligo and psoriasis. We aim to explore the regulatory mechanism of AQP3 and the function of AQP3 on the skin. We summarize the distribution of $A Q P 3$ in skin and the regulatory mechanism of $A Q P 3$, then point out the function of AQP3 on the skin and the development trend of AQP3 as a new target in the field of cosmetic research.
\end{abstract}

Keywords: Aquaporin 3, Skin, Regulation, Moisturizing, Anti-aging

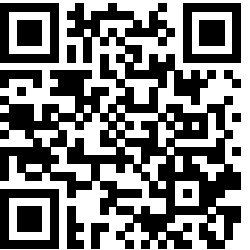

\section{Introduction}

水通道蛋白（Verkman et al., 2008）是上世纪90年代发 现的一类在细胞膜上与水分子通透性有关的转运蛋白。 迄今为止，共有 200 余种水通道蛋白在不同物种中被发 现，其中有13种水通道亚型存在于哺乳动物体内，分别 被命名为AQP0-12（Takata et al., 2004）。根据水通道蛋 白转运功能特异性的差异, 将其分为两个亚家族（HaraChikuma \& Verkman, 2008; Jung et al., 1994）：其中一个 是水选择通道亚家族，包括 $A Q P 1 、 A Q P 2 、 A Q P 4 、 A Q P 5 、$ AQP6、AQP8、和 $A Q P 0$; 另一个是水-甘油通道亚家族, 包 括AQP3、AQP7、AQP9和AQP10。对于AQP11和AQP12, 其生理功能尚不清楚, 但是有研究显示 (Morishita et al., 2004），可能参与器官形成。

AQPs广泛分布于机体器官及组织细胞中（Geng \& Yang, 2014; Hara-Chikuma et al., 2009; Venero et al., 2001) , 尤其与液体分泌和吸收有关的上皮细胞和内皮细胞含量颇
丰, 参与水的分泌、吸收及细胞内外水的平衡。然而, 在 皮肤中表达的水通道蛋白只有AQP3（Verkman, 2011），它 属于水一甘油通道蛋白亚家族。通过调研发现, AQP3与特 异性皮炎、银屑病、白瘕风、皮肤肿瘤等皮肤疾病的发生 密切相关。故主要从AQP3在皮肤中的分布, AQP3的调控机 制以及AQP3对人类皮肤的作用三个方面进行综述，为通过 调节AQP3来护肤的相关化妆品的研发提供科学依据。

\section{Composition and distribution of AQP3 in skin}

1994 年，Ishibashi et al.（1994）发现了AQP3，其含有 279 个氨基酸, 相对分子质量约为 $29 \times 10^{3}$ 。 AQP3 是一 种跨膜蛋白, 最早被报道是在表皮角质形成细胞中表达

(Matsuzaki et al., 2004）。而且通过调研发现（Silberstein etal., 1999），其在表皮的分布主要表达于基底层以上角质 层以下部分, 其中在基底层的角质形成细胞膜上的表达 
最为强烈, 随着角质形成细胞的分化和向上移动而逐渐 减少, 到角质层完全消失。AQP3 在人表皮的这种分布与 人表皮水分的分布情况是一致的, 与角质层和颗粒层交 界处的水分梯度相符合（Tang, 2008）。

\section{Regulation mechanism of AQP3}

\section{Effects of genes, hormones, and cytokines}

通过对水通道蛋白结构的分析 (Jung et al., 1994) 发现 AQP3蛋白分子中具有蛋白激酶磷酸化位点, 即蛋白激酶A (protein kinase A, PKA) 、蛋白激酶C (protein kinase C, PKC）或者蛋白激酶 G（protein kinase G, PKG）的同源序 列。研究发现（Itoh et al., 2004; Wu et al., 2014），当腺 苷酸环化酶 (adenylate cyclase, AC) 被激活, 会导致细胞内 环磷酸腺苷 (cyclic adenosine monophosphate, CAMP) 的含 量增加, 进一步激活PKA、PKC或者PKG, 从而促进AQP3基 因的转录。研究发现当激素失衡时, 激素通过过氧化物酶体 增殖物激活受体y (peroxisome proliferators-activated receptor $\gamma, P P A R G$ ）-肿瘤坏死因子 $a$ （tumor necrosis factor $\alpha$, TNFA）－磷脂酰肌醇-3-羊弪激酶（phosphatidylinositol 3-hydroxy kinase, PI3K) -雷帕霉素靶蛋白 (mammaliantarget rapamycin, mTOR)、PKA、PKC三个通路抑制AQP3基因 的转录 (Asai et al., 2006)。而Nader和Kino等（Kino \& Chrousos, 2011; Nader et al., 2009）发现, Clock基因是一个 可以调节皮肤 $24 \mathrm{~h}$ 节律的基因, 时钟基因CLOCK和BMAL1直 接结合human AQP3 (hAQP3) 启动器的响应元件 (D-site) E-box) 来激活其转录, 同时, 它可以通过抑制激素受体的 转录活性, 从而维持激素正常功能, 进而调控AQP3的表达 （Matsunaga et al., 2014）。故推测，Clock基因通过调节 激素受体的活性调节激素达到正常水平, 进而通过磷酸化 途径影响 $A Q P 3$ 基因的转录, 从而调控AQP3的表达。

除此之外, 血管活性肠肽可增加AQP3的表达; 肿瘤坏死 因子TNFA可以抑制AQP3的表达 (Cao et al., 2006; Horie et al., 2009; Murai et al., 2008) 。

\section{Effects of physical and chemical properties of internal and external environment}

由于细胞与内环境之间、内环境与外界环境之间不断地 进行着物质交换, 因此内外环境的不断变化, 必然会影响 细胞的代谢活动。通过调研发现, AQP3的表达亦受到内 外环境理化性质的影响。研究显示, 在含有山梨醇、氯化 钠、甘露醇及糖类等的高的渗透压环境下, AQP3 mRNA的 表达是增加的, 所以可知, AQP3的表达受渗透压环境的影
响（Garcia et al., 2011）。而且, 水通道蛋白的表达还受氧 浓度的影响（Fujita et al., 2003）。在低氧条件下, AQP3的 mRNA及蛋白的表达均出现明显的降低。另外, 在 $\mathrm{pH}=6.0$ 的 条件下, AQP3 表现为甘油通道, 而当 $\mathrm{pH}<5.6$ 时, 细胞完 全失去对水和甘油分子的通透性 (Zheng \& Bollinger Bollag, 2003）, AQP3对水的通透能力是与pH有关的 (NémethCahalan et al., 2004)。AQP3的通透性还受 $\mathrm{Cu}^{2+}$ 和 $\mathrm{Ni}^{2}+$ 的抑制 作用, 分子中的细胞外氨基酸残基Trp128、Ser152和His 241 与C $\mathrm{U}^{2+}$ 相关, 特别是Ser152还参与酸碱度调控AQP3 渗透性 的过程（Ikarashi et al., 2012）。所以, AQP3的表达与细胞 赖以生存的内环境有密切的联系。

\section{Effects of AQP3 on human skin}

\section{Relationship between $A Q P 3$ and skin moisture}

1) The function of transferring water

研究表明（Itoh et al., 2003），AQP3可将体内循环中的水 分带入表皮, 在表皮细胞基底层至角质层间提供一种短的 水回路, 从而保证表皮持续的水含量, 对于表皮的屏障作 用、水的保存有很大的意义。目前已经有研究证实 (Bonté, 2011; Zhang \& Li, 2013) , 通过调节AQP3的表达, 可以改变 干燥性皮肤病的皮肤含水量, 减少水分丢失。

2) The function of transferring glycerol

AQP3 不仅可以运送水, 同时还能从循环中将内源性甘 油、皮脂腺中的甘油三脂带入表皮, 进而参与表皮细胞甘 油代谢, 表皮角质形成细胞合成的甘油三脂和皮脂腺分泌 的甘油三脂都是角质层中甘油的来源, 而角质层甘油的含 量是影响皮肤含水量的重要因素之一, 对于保持皮肤的含 水量也十分重要（Schrader et al., 2012），故AQP3转运甘 油成为皮肤保湿的另一途径。

3) Synergistic effects of $A Q P 3$ and filaggrin

中间丝相关蛋白是参与皮肤表皮角质包膜形成的重要蛋 白, 形成表皮角质层独特的屏障结构, 从而维持皮肤正常 含水量, 防止皮肤水分散失。研究者发现 (Hara-Chikuma et al., 2015），当用tape stripping破坏皮肤屏障，或者用醚

(ether) /丙酮 (acetone) 去除脂质造成皮肤屏障功能受 损时, AQP3表达会立即增高, 并且在屏障破坏后 24 h增高 最明显。而在屏障破坏后 $3 \mathrm{~h}$, 中间丝相关蛋白的表达出现 短暂而明显的下降, 并在 $24 \mathrm{~h}$ 恢复正常。中间丝相关蛋白 水解后可提供天然保湿因子 (natural moisturizing factor, $N M F)$, 主要是氨基酸, $L$-谷氨酰胺、 $L$-谷氨酸衍生物、吡 
咯烷酮羧酸。造成此显现的原因是, 当皮肤屏障遭到破坏 后, 导致渗透压应激, 作为缺水的立即反应, 中间丝相关 蛋白降解产生新的NMF成分, 而AQP3 则作为迟发的二次反 应接替中间丝相关蛋白的作用。因此, AQP3与中间丝相关 蛋白的这种协同作用为细胞提供充足的水环境, 从而重建 皮肤屏障达到保湿功效。

4) Relationship between $A Q P 3$ and tight junction protein 紧密连接相关蛋白（tight junction, TJ) 通常位于上皮顶 端两相邻细胞间, 在皮肤中的表达对皮肤屏障功能至关重 要。张文杰（Zhang et al., 2012）等, 利用靶向AQP3的 shRNA技术, 通过 reverse transcription-polymerase chain reaction (RT-PCR) 和Western blot法及免疫细胞化学法 检测和观察了干扰AQP3的表达后, 其对TJ主要构成蛋白 Occludin和Claudin-1的影响并探讨了其可能机制。结果显 示, 干扰AQP3的表达后, Occludin和Claudin-1的表达明显 降低, 且TJ结构遭到破坏。推测其可能的机制是, PKC通路 在TJ中发挥着重要的作用, Suzuki et al. (2009) 发现PKC 可使Occludin中C端结构域苏氨酸磷酸化, 调节TJ功能; 还 有研究发现PKC可磷酸化人Claudin-4的第194个丝氨酸, 进而影响TJ功能（Aono \& Hirai, 2008）。而AQP3分子中含 有蛋白激酶磷酸化位点, 因此AQP3也可能是通过PKC通路 影响TJ功能, 从而影响皮肤屏障功能, 进而影响皮肤的保 湿, 但其具体机制仍需进一步研究。

\section{Relationship between $A Q P 3$ and skin aging}

研究显示 (Tang, 2008) , 在不同年龄段, AQP3 mRNA 及蛋白在皮肤中的表达是有差异的。Hara-Chikuma et al. (2015) 取55例健康人腹部皮肤, 按年龄分为青年组 (<20岁) 、中年组（30-45岁）和老年组（>55岁）, 反 转录聚合酶链反应及蛋白质印迹法检测发现, 老年组皮肤 中AQP3表达量显著低于中年组, 中年组皮肤中AQP3显著低 于青年组。AQP3 mRNA及蛋白随年龄的增加而逐渐减少。

另外, 在一项对AQP3缺乏的小鼠的生物学研究中（Qin et al., 2011) , 当AQP3含量降低时, 甘油的新陈代谢 和生物合成受损, 一方面导致三磷酸腺苷 (adenosine triphosphate, ATP) 含量降低, 接着丝裂原激活的蛋白激酶

(mitogen-activated protein kinase, MAPK) 信号也会因此 被破坏, 从而降低了细胞的增殖能力, 促进细胞凋亡; 另 外, 甘油含量的降低也会导致脂类合成受损, 从而也会影 响细胞增殖。细胞增殖能力降低又会导致AQP3合成减少, 如此形成一个循环, 促进细胞的死亡。相反, 当AQP3含量 升高, 可以为细胞增殖提供ATP, 增强细胞活力, 延缓皮肤 衰老。

\section{Conclusion}

AQP3是皮肤中表达最明显的水通道蛋白亚型。AQP3不仅 可以转运水, 也可以转运甘油、尿素等小分子物质, 与此 同时, AQP3也可以影响与皮肤屏障相关的蛋白, 如协同中 间丝相关蛋白、调节紧密连接相关蛋白的表达, 此功能对 $\mathrm{AQP} 3$ 维持皮肤表皮的水合作用, 修复皮肤屏障具有重要意 义。除此之外, AQP3可以为细胞增殖提供ATP, 增强细胞 活力, 降低细胞凋亡, 延缓衰老。

另外，本文对AQP3的调控机制进行了深入的总结，时钟基因、 磷酸化作用等均可以通过相应通路来调控AQP3的表达。

通过对AQP3的调控机制及对人皮肤的作用的总结, 阐明 了调节AQP3的表达可以有效的调节皮肤的状态, AQP3作为 化妆品领域功效研究新靶点, 具有良好的前景。

\section{References}

Aono S, Hirai Y. Phosphorylation of claudin-4 is required for tight junction formation in a human keratinocyte cell line. Experimental Cell Research, 314: 3326-3339, 2008.

Asai M, Higuchi S, Kubota M, Iguchi K, Usui S, Hirano K. Regulators for blood glucose level affect gene expression of aquaporin 3. Biological and Pharmaceutical Bulletin, 29: 991-996, 2006.

Bonté F. Skin moisturization mechanisms: new data. Annales Pharmaceutiques Françaises, 69: 135-141, 2011.

Cao C, Sun Y, Healey S, Bi Z, Hu G, Wan S, Kouttab N, Chu W, Wan Y. EGFR-mediated expression of aquaporin-3 is involved in human skin fibroblast migration. Biochemical Journal, 400: 225-234, 2006.

Fujita Y, Yamamoto N, Sobue K, Inagaki M, Ito H, Arima H, Morishima T, Takeuchi A, Tsuda T, Katsuya H, et al. Effect of mild hypothermia on the expression of aquaporin family in cultured rat astrocytes under hypoxic condition. Neuroscience Research, 47: 437-444, 2003.

Garcia N, Gondran C, Menon G, Mur L, Oberto G, Guerif Y, Dal Farra C, Domloge N. Impact of AQP3 inducer treatment on cultured human keratinocytes, ex vivo human skin and volunteers. International Journal of Cosmetic Science, 33: 432-442, 2011.

Geng X, Yang B. The physiological functions of aquaporins. Journal of Physiology Studies, 2: 19-32, 2014.

Hara-Chikuma M, Satooka H, Watanabe S, Honda T, Miyachi 
Y, Watanabe T, Verkman AS. Aquaporin-3-mediated hydrogen peroxide transport is required for NF-KB signalling in keratinocytes and development of psoriasis. Nature Communications, 6: 7454, 2015.

Hara-Chikuma M, Takahashi K, Chikuma S, Verkman AS, Miyachi Y. The expression of differentiation markers in aquaporin-3 deficient epidermis. Archives of Dermatological Research, 301: 245-252, 2009.

Hara-Chikuma M, Verkman AS. Aquaporin-3 facilitates epidermal cell migration and proliferation during wound healing. Journal of Molecular Medicine, 86: 221-231, 2008.

Horie I, Maeda M, Yokoyama S, Hisatsune A, Katsuki H, Miyata T, Isohama $Y$. Tumor necrosis factor- $\alpha$ decreases aquaporin-3 expression in DJM-1 keratinocytes. Biochemical and Biophysical Research Communications, 387: 564-568, 2009.

Ikarashi N, Ogiue N, Toyoda E, Kon R, Ishii M, Toda T, Aburada T, Ochiai W, Sugiyama K. Gypsum fibrosum and its major component $\mathrm{CaSO}_{4}$ increase cutaneous aquaporin-3 expression levels. Journal of Ethnopharmacology, 139: 409-413, 2012.

Ishibashi K, Sasaki S, Fushimi K, Uchida S, Kuwahara M, Saito H, Furukawa T, Nakajima K, Yamaguchi Y, Gojobori $\mathrm{T}$, et al. Molecular cloning and expression of a member of the aquaporin family with permeability to glycerol and urea in addition to water expressed at the basolateral membrane of kidney collecting duct cells. Proceedings of the National Academy of Sciences of the United States of America, 91: 6269-6273, 1994.

Itoh A, Tsujikawa T, Fujiyama Y, Bamba T. Enhancement of aquaporin-3 by vasoactive intestinal polypeptide in a human colonic epithelial cell line. Journal of Gastroenterology and Hepatology, 18: 203-210, 2003.

Itoh A, Tsujikawa T, Yasuoka T, Nakahara T, Sasaki M, Fujiyama Y. Natriuretic peptides up-regulate aquaporin 3 in a human colonic epithelial cell line. International Journal of Molecular Medicine, 14: 621-626, 2004.

Jung JS, Preston GM, Smith BL, Guggino WB, Agre P. Molecular structure of the water channel through aquaporin CHIP: the hourglass model. The Journal of Biological Chemistry, 269: 14648-14654, 1994.

Kino T, Chrousos GP. Acetylation-mediated epigenetic regulation of glucocorticoid receptor activity: circadian rhythm-associated alterations of glucocorticoid actions in target tissues. Molecular and Cellular Endocrinology, 336: 23-30, 2011.

Matsunaga N, Itcho K, Hamamura K, Ikeda E, Ikeyama H, Furuichi Y, Watanabe M, Koyanagi S, Ohdo S. 24-Hour rhythm of aquaporin-3 function in the epidermis is regulated by molecular clocks. Journal of Investigative Dermatology, 134: 1636-1644, 2014.

Matsuzaki T, Tajika Y, Ablimit A, Aoki T, Hagiwara H, Takata K. Aquaporins in the digestive system. Medical Molecular Morphology, 37: 71-80, 2004.

Morishita Y, Sakube Y, Sasaki S, Ishibashi K. Molecular mechanisms and drug development in aquaporin water channel diseases: aquaporin superfamily (superaquaporins): expansion of aquaporins restricted to multicellular organisms. Journal of Pharmacological Sciences, 96: 276-279, 2004.

Murai H, Terada A, Aoyama M, Kusabe T, Fujisawa T, Asai K, Togari $H$. Dexamethasone inhibits down regulation of AQP3 stimulated by TNF-a. The Journal of Allergy and Clinical Immunology, 121: S259, 2008.

Nader N, Chrousos GP, Kino T. Circadian rhythm transcription factor CLOCK regulates the transcriptional activity of the glucocorticoid receptor by acetylating its hinge region lysine cluster: potential physiological implications. The FASEB Journal, 23: 1572-1583, 2009.

Németh-Cahalan KL, Kalman K, Hall JE. Molecular basis of $\mathrm{pH}$ and $\mathrm{Ca}^{2+}$ regulation of aquaporin water permeability. The Journal of General Physiology, 123: 573-580, 2004.

Qin H, Zheng X, Zhong X, Shetty AK, Elias PM, Bollag WB. Aquaporin-3 in keratinocytes and skin: its role and interaction with phospholipase D2. Archives of Biochemistry and Biophysics, 508: 138-143, 2011.

Schrader A, Siefken W, Kueper T, Breitenbach U, Gatermann C, Sperling G, Biernoth T, Scherner C, Stäb F, Wenck H, et al. Effects of glyceryl glucoside on AQP3 expression, barrier function and hydration of human skin. Skin Pharmacology and Physiology, 25: 192-199, 2012.

Silberstein C, Kierbel A, Amodeo G, Zotta E, Bigi F, Berkowski $D$, Ibarra C. Functional characterization and localization of AQP3 in the human colon. Brazilian Journal of Medical and Biological Research, 32: 1303-1313, 1999.

Suzuki T, Elias BC, Seth A, Shen L, Turner JR, Giorgianni F, Desiderio D, Guntaka R, Rao R. PKCn regulates occludin 
phosphorylation and epithelial tight junction integrity. Proceedings of the National Academy of Sciences of the United States of America, 106: 61-66, 2009.

Takata K, Matsuzaki T, Tajika Y. Aquaporins: water channel proteins of the cell membrane. Progress in Histochemistry and Cytochemistry, 39: 1-83, 2004.

Tang $H$. Expression of AQP3 in normal human skin, keratinocytes and fibroblasts at different ages. Doctor's Thesis, Central South University, 2008.

Venero JL, Vizuete ML, Machado A, Cano J. Aquaporins in the central nervous system. Progress in Neurobiology, 63: 321-336, 2001.

Verkman AS, Hara-Chikuma M, Papadopoulos MC. Aquaporins-new players in cancer biology. Journal of Molecular Medicine, 86: 523-529, 2008.

Verkman AS. Aquaporins at a glance. Journal of Cell Science, 124: 2107-2112, 2011.
Wu Z, Uchi H, Morino-Koga S, Shi W, Furue M. Resveratrol inhibition of human keratinocyte proliferation via SIRT1/ ARNT/ERK dependent downregulation of aquaporin 3. Journal of Dermatological Science, 75: 16-23, 2014.

Zhang JX, Li ZJ. Research progress in role of AQP3 in pathogenesis of skin diseases. Medical Recapitulate, 19: 3101-3103, 2013.

Zhang WJ, Xu Y, Wang B, Xu H. Lentiviral-mediated delivery of shRNA targeting aquaporin 3 alters tight junction protein expression and distribution in Caco-2 cells. World Chinese Journal of Digestology, 20: 1973-1977, 2012.

Zheng X, Bollinger Bollag W. Aquaporin 3 colocates with phospholipase d 2 in caveolin-rich membrane microdomains and is downregulated upon keratinocyte differentiation. Journal of Investigative Dermatology, 121: 1487-1495, 2003. 


\section{中文摘要}

\section{水通道蛋白AQP3调控机制及对皮肤作用研究进展}

王笑月，薛燕，董泽原，董银卯，李丽*

北京工商大学中国化妆品协同创新中心, 北京, 中国

水通道蛋白3 (AQP3) 在特异性皮炎、白癜风、银屑病等疾病中发挥着重要的作用, 旨在通过AQP3对皮肤疾病的影响, 探索其调控机制及对皮肤的作用。本文总结了AQP3在皮肤中的分布, 及其调控机制, 指出了其对皮肤的影响以及AQP3作 为化妆品领域研究新靶点的发展方向。

关键词: 水通道蛋白, 皮肤, 调控, 保湿, 延缓衰老 


\section{국문초록}

\section{수분통로단백질 AQP3의 조절 메커니즘과 피부작용에 대한 연구}

왕소월, 설연, 동탁원, 동인묘, 리려*

북경공상대학 중국화장품공동혁신센터, 북경, 중국

수분통로단백질인 aquaporin 3 (AQP3)은 백반증, 건선 등 다양한 피부 관련 질병의 발현에 중요한 역할을 한다. 본 연구에서는 AQP3 가 피부질환에 미치는 영향을 확인함으로써, $\mathrm{AQP3}$ 의 피부 속 조절 메커니즘 및 피부작용에 대해 연구하고자 한다. 이를 위해 피부에 서 $\mathrm{AQP3}$ 의 전달 및 기능을 요약한 후 향후 화장품 영역에서 $\mathrm{AQP} 3$ 의 새로운 발전 방향을 밝히고자 한다.

핵심어: 수분통로단백질, 피부, 조절, 보습, 노화지연 